\title{
APPLICATION OF CREATIVITY IN THE EDUCATIONAL PROCESS
}

Ivana Dudová ${ }^{\text {, Jakub Cíba }}{ }^{2}$

\begin{abstract}
Creativity is the engine, and motivation and hard work is the petrol on the road to success. The aim of this article was to present and demonstrate the crucial and important role of creativity in education. In this sense, the article explains the contents of important concepts such as creativity, creative teaching, motivational climate, and teaching methods for developing students' creativity in teaching. Attention is drawn in particular to the presence of creativity in education at the University of Žilina.
\end{abstract}

JEL Classification Numbers: R10, R11, I23, DOI: http://dx.doi.org/10.12955/cbup.v3.589

Keywords: creativity, educational process, university, students, teacher

\section{Introduction}

Increasingly often, we encounter the term creativity, which represents a specific set of skills that allow for successful realization in scientific, artistic, or any other areas of human activities. Creativity is an activity of a person that creates new material, technical, cultural, and spiritual values. Creativity can be transferred from a theoretical point of view into the practical aspects of the educational process. The pedagogue has to set a good example for his or her students on how to become a creative person. Many years ago, a teacher named John Amos Komenius described the school as a workshop of creativity, preparing its students properly for their lives. It is important to include practice and exercises to improve creativity in the educational process. It is up to the teacher whether the educational process takes place in a standard manner or in the form of a creative game. While it does not negatively affect the structure and the desired outcome of the educational process, it helps the students develop their capacity for creativity.

Individual elements of creativity can, of course, be affected separately in different ways. Many factors, both internal and external environment of the students, can cause various outcomes in creative performance for various individuals.

\section{The importance of creativity}

"Creativity is a psychological activity, which employs an unorthodox approach to an object, originality, ingenuity, initiatives, etc. Creativity represents an ability of high value, thus justifying any time necessary in order to be obtained” (Žák, 2004). Because the goal of an educational process is not only to acquire knowledge, but also to be able to create, which is not always an easy task. We would all like to know how to raise a strongly creative person and how to cultivate their talents in a world full of critical situations and conflicts, as creativity is as much about creating new, unique visions as it is about solving old problems in a new, never-before-seen manner. It is an activity that delivers economically valuable creations and products not known to date. In the past, the educational system has mostly valued only raw knowledge, but in our present information economy there are many more aspects to the educational process that have to be taken into consideration—one of which is creativity (Clegg \& Birch, 2005).

Zelina \& Zelinová (1990) defined four reasons why it is important to put emphasis on creativity in the educational process. The first reason is based on raising individuals for the future. People will be pressured to process much more information, undergo much more critical thinking, and apply new methods. The second reason lies in the cooperation with scientific research. The needs of the industry represent the third reason, which cannot be fulfilled by raising and educating students with the old

\footnotetext{
${ }^{1}$ Ing. Ivana Dudová, University of Žilina in Žilina, Faculty of Operation and Economics of Transport and Communications, Department of Communications, ivana.dudova@fpedas.uniza.sk

2 Ing. Jakub Cíba, University of Žilina in Žilina, Faculty of Operation and Economics of Transport and Communications, Department of Communications, jakub.ciba@fpedas.uniza.sk
} 
methods; instead, modernization, innovation, and actualization of both content and methods, forms and resources of raising and educating students have to be utilized. The fourth reason is social and humane-in creative work, one can find happiness, realization, and meaning of life.

Creativity as a process, whose main principle is the transformation, choice and rearrangement of elements through previous experience by combining novelty and usefulness. Musil, in Dacey \& Lennon (2000), suggests five stages of creative process, so called PASPSA, which can be applied for developing the creativity of students:

- P - perception - perceiving problems, impulses;

- A - analysis - analyzing situations, problems, setting goals;

- SP - synthesis and production - producing ideas, alternatives, and solutions;

- $\mathrm{S}$ - selection - choosing the best solution;

- A - application - applying the ideas against the obstacles.

The general approach, therefore, ensures a complex development of an individual's creative personality capacity. Creativity and imagination are two of the key factors for future success, and not just for the gifted individuals. Raising individuals as a directed effort of adults should motivate the raised individuals to choose such a strategy of using resources that will respect their individuality and the usage of free will toward one's own responsibility. An individual raised in this way would be able to solve problems as stimulating creative tasks.

\section{Creative tuition method and motivational environment}

Creating a general interest for learning and inner motivation for studying plays a major role in directing creative activities in an educational institution. The use of knowledge has to also be connected to an application of creativity. Creativity has a reverse effect on knowledge in such a way that it motivates and stimulates the student to learning further after which new knowledge allows them to create on a higher level.

The ability to motivate students depends on the personality of the pedagogue and his or her own creative work. Every teacher has a unique personality, which creates a specific educational climate in the classroom in the form of interaction with students and enables creative inspiration. This climate is mostly the creation of the pedagogue even if it is partially affected by the students also.

Pedagogues are individuals, whose professional activity includes providing knowledge, approaches, and skills that are specified in the formal programs for the students registered at the educational institutions. They are the partakers of tutoring and deciding what form will it take. They occupy a motivational role in which they are tasked to hold the students' attention, activity, independence, and creativity.

Both the student and the pedagogue can be the subjects of creativity. The pedagogue should not only wait untill the student develops a creative idea, instead he or she should elaborately and systematically create an atmosphere and motivation that would lead students toward creative thinking.

During the instruction, a creative pedagogue should notice how well does the chosen form of tuition suit the students and be ready to adjust the learning pace, difficulty, and complexity when needed.

Creativity of pedagogues manifests especially by their effort to support the forming of ideas and critical thinking of students, so that the students make decisions by themselves, form informal relationships, act spontaneously, and foster a climate of openness, trust, and focus on studying (Ďuričeková, 1998).

Strategies for cultivating the creative potential: 
1. Be an example of creativity.

2. Support doubts about claims.

3. Admit errors.

4. Support reasonable risk taking.

5. Introduce a creative process into tuition and evaluation.

6. Appeal for others to define and redefine problems.

7. Reward performance and good ideas.

8. Provide a lot of time for creative thinking.

9. Be willing to cultivate yourself.

10. Alert others about obstacles which they will have to face and overcome.

11. Realize the importance of relationships between a person and the environment (Dargová, 2001).

Zelina (1995) defined characteristics/attributes of a creative student as:

- much curiosity, desire for knowledge and imagination,

- the effort to solve given problems with ambiguity and uncertainty,

- tendencies toward an entrepreneurial spirit, fun, and games,

- tendencies toward independence and self-realization,

- sense for beauty, emotional perceptiveness, and sense of humor,

- unusual solutions and ideas, interest for unusual and atypical approaches,

- choosing more difficult tasks, willingness to risk, and setting higher goals,

- a wide variety of interests,

- lack of ever being fully satisfied with own work,

- ability to decide correctly in an unclear situation.

A positive climate and good conditions for creative work are the prerequisites for the existence of creative students in the educational system on order to implement and create new ideas. Basic characteristics of a creative educational climate:

- thinking, creation, alternatives, and experimenting are appreciated,

- freedom of thought and specialization is allowed,

- self-confidence and self-evaluation are encouraged,

- originality and new ideas are stimulated,

- openness to others, teamwork, and healthy criticism are promoted,

- everyone participates on the evaluation of work, people, and relationships,

- positive orientation on work, optimism, and belief in own creative powers are supported.

Searching, learning, self-evaluation, and a strong belief in the skills of the students are favored in a creative climate. Independence, sense for order, and discipline are in harmony with a student's creative work. A part of an educational process directed toward promoting creativity should create enough room for invention and development of ideas and solutions, encouraging curiosity that creates a desire for finding creative solutions to problems, motivation towards learning, and supporting uncommon ideas and solutions. Creating an atmosphere of contentment, freedom, spontaneity, and playfulness 
while learning should also play an equally important role. Creativity is affected by many positive and negative conditions. Among the behaviorally negative ones are emotional, perceptional, intellectual and expressional; the institutionally negative ones include unsuitable learning space, lack of learning tools, wrong teaching methods, or subjective evaluation of students by the pedagogues (Lokšová \& Lokša, 1996).

\section{The presence of creativity in the educational process of University of Žilina}

An interesting area of study lies in the research of the degree to which creativity poses an integral component of the educational process at University of Žilina (hereinafter "UNIZA"). To that end, a primary research on 1993 students across every faculty of UNIZA (UŽ) has been conducted. A questionnaire was used as a tool of the research. Respondents were asked to express their opinions about the existence of creativity within their own study programs. First question was aimed at the presence of courses within a study program using or containing creativity techniques, creative thinking, and creative entrepreneurship.

Based on the answers from the respondents, it can be determined that the educational process at UŽ includes courses that promote creativity and develop knowledge and experience of the students in this area.

Next, we were interested in whether the pedagogues of UŽ employ creative techniques and methods in their teaching process.

The results showed that pedagogues at UŽ do support the thinking and ideas of students and create a climate of openness, trust, and creativity. Based on the next question asked, we have discovered that many students consider themselves to have creative personalities, thus demonstrating the typical attributes for a creative student.

Question: Are there courses that are aimed toward creativity techniques, creative thinking, and creative entrepreneurship within your program of study?

\begin{tabular}{|c|ccccc|c|c|}
\hline Figure 1: Presence of creativity in the courses per faculty & & & & & & \\
\hline
\end{tabular}


Question: Did you experience the use of creativity techniques and methods in the teaching process of at least one pedagogue?

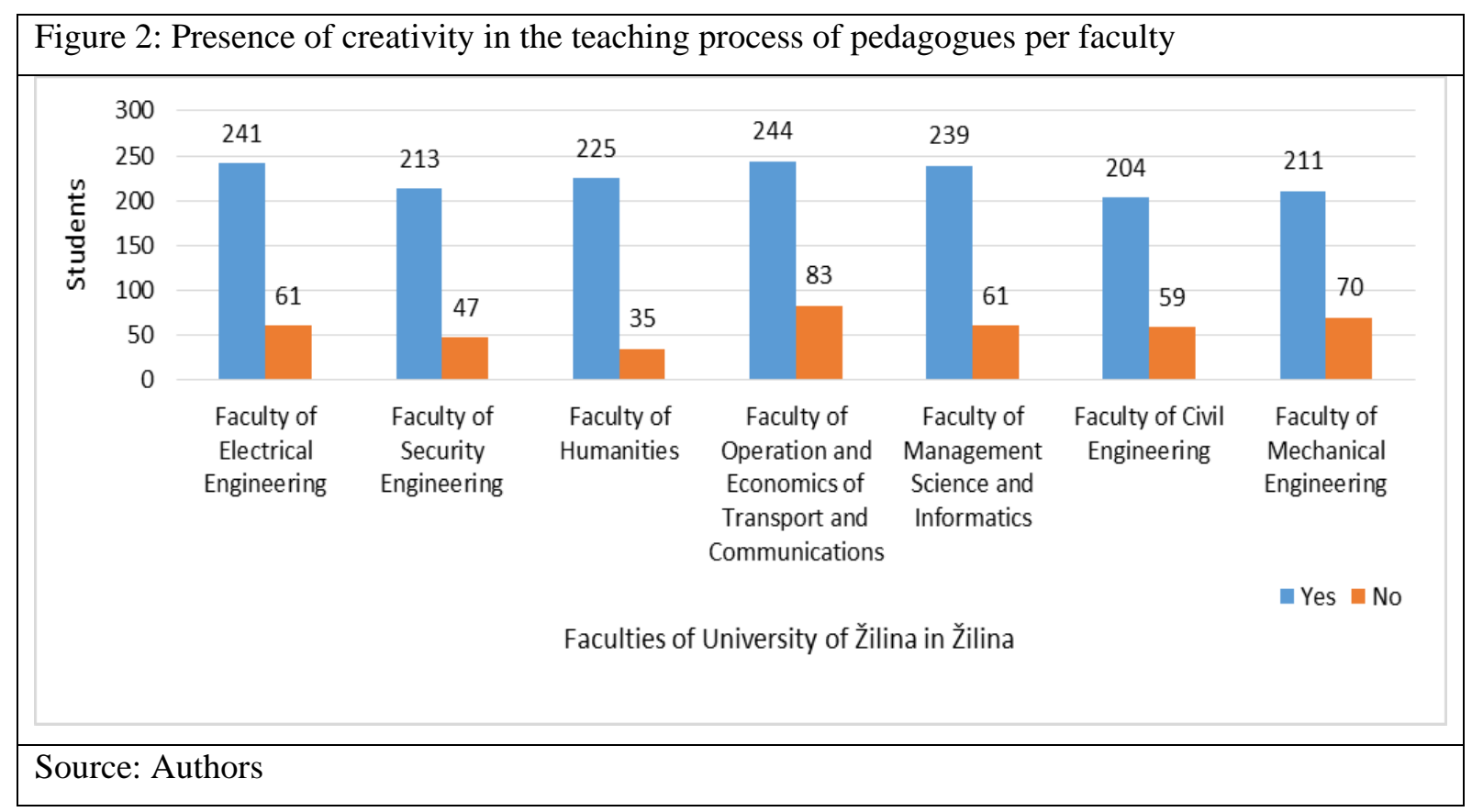

Question: Do you consider yourself to have a creative personality?

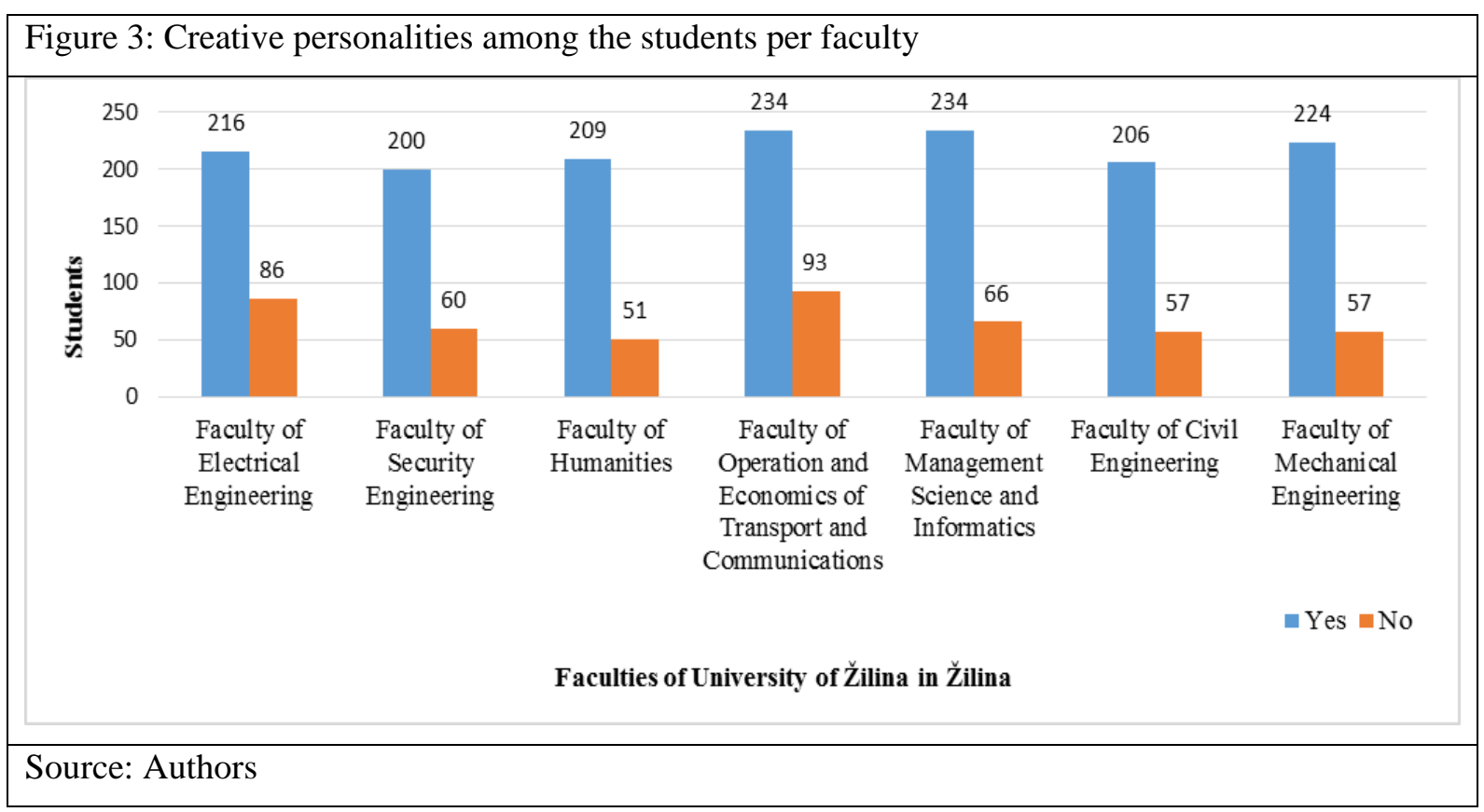

\section{Methods of cultivating creativity for students in the educational process}

Creativity is one of the most significant characteristic of a person that reflects his or her most valuable and humane attributes. By developing creativity, the student is given an opportunity for a richer inner life and richer self-realization options. In the educational process, development of creativity is perceived as a formative influence over the student-an inner development of his or her dispositions and conditions for creative activity. Creative potential represents an accumulation of skills, personality traits, knowledge, and motivation used for creative processes. 
The conception of creative teaching means a systematic use of teaching methods, goals, didactic rules, organizational forms, and material resources leading to it.

According to Zelina (1995), a basic method of developing creativity is the formation of creative tasks. In order for a creative task to cultivate creativity, it has to:

- bring surprise into teaching - to present cases, that are not compliant with expectations;

- cause doubt, let the students use assessment and intuition;

- cause cognitive uncertainty - a problem, that can have many solutions;

- assign difficult, almost unsolvable tasks;

- establish self-contradictory statements;

- dramatize.

How to raise the interest of a student?

- show your own interest—be enthusiastic about your own area of expertise;

- show the importance of every activity-bring case examples in the educational process, use instructional movies, and excursions with other experts from multidisciplinary teams;

- use creativity;

- make sure that the student actively participates in the educational process;

- regularly alter activities of the student during an educational unit;

- use surprises and uncommon activities;

- assign highly competitive and problematic tasks to groups of students;

- add a personal dimension to one’s own work.

\section{Methods for cultivating creativity}

1. methods and techniques for creation of divergent tasks (tasks that do not contain a clear solution).

2. teaching strategies that promote creativity.

3. methods with tasks aimed at ingenuity.

4. methods for cultivating perception, imagination and intuition.

5. methods for improving flexibility, originality and thought originality.

6. methods for improving creative evaluation-discussions, creativity in communication.

7. methods of creative problem solving (Petty, 1996).

\section{Conclusion}

Creativity is a set of skills that allows productive activities. More and more often, we encounter theoretical definition of the term creativity and its development in the field of education. The main goal and task of education are to create conditions for every student to strengthen his or her attitude toward gaining new experience. Each person, whether a student or not, should always strive to expand his or her knowledge for one's own benefit. The desire to discover and understand must have a higher personal value than just a formal assessment.

Pedagogues in the educational process should support the desires and efforts of students in search of knowledge and encourage and reward their creative ideas. They should get to know themselves, their own abilities, and choices, because it is necessary to develop creativity at every age. The creativity of 
a pedagogue lies within his or her inventiveness of themes and in providing creative space to students. A creative pedagogue is one who does not work stereotypically but constantly reflects upon his or her work, has a wide variety of interests, searches for new ideas, and can be enthusiastic about a subject that could promote creativity, combinative skills, and imagination in the students.

\section{Acknowledgement}

This article was supported by the project "Universities and regional innovation systems (UNIRIS)."

\section{References}

Clegg, B., \& Birch, P. (2005). Kreativita [Creativity]. Brno: CP Books.

Dacey, S. J., \& Lennon, H. K. (2000). Kreativita [Creativity]. Praha: Grada Publishing.

Dargová, J. (2001). Tvorivé kompetencie učitel'a [Creative competence of the teacher]. Prešov: Privatpress.

Ďuričeková, M. (1998). Tvorivost' učitel’a [Creativity teacher]. Pedagogická revue [Education Review], 50(2).

Lokšová, I., \& Lokša, J. (1996). Cez relaxáciu $k$ tvorivosti $v$ škole. 1 vyd [Through relaxation to creativity in school (1st ed.)]., Prešov: ManaCon.

Petty, G. (1996). Moderní vyučování [Modern teaching]. Praha: Portál.

Zelina, M. (1995). Výchova tvorivej osobnosti [Creative personality in Education]. Bratislava, Slovakia: Univerzita Komenského.

Zelina, M., \& Zelinová, M. (1990). Rozvoj tvorivosti deti a mládeže [Developing the creativity of children and youth]. Bratislava, Slovakia: SPN.

Žák, P. (2004). Kreativita a její rozvoj [Creativity and its development]. Brno: Computer Press. 